\title{
Novel Insights into the Mode of Action of Vasorelaxant Synthetic Polyoxygenated Chalcones
}

\author{
Samuel Legeay ${ }^{1, *}\left(\mathbb{D}\right.$, Kien Trân ${ }^{2}$, Yannick Abatuci ${ }^{2}$, Sébastien Faure ${ }^{1}(\mathbb{D}$ and \\ Jean-Jacques Helesbeux ${ }^{2}$ (D) \\ 1 MINT, UNIV Angers, INSERM 1066, CNRS 6021, IRIS-IBS-CHU, 4 Rue Larrey, 49100 Angers, France; \\ sebastien.faure@univ-angers.fr \\ 2 SONAS, EA921, UNIV Angers, SFR QUASAV, Faculty of Health Sciences, Dpt Pharmacy, 16 Bd Daviers, \\ 49045 Angers CEDEX 01, France; Kien.Tran@usherbrooke.ca (K.T.); yannick.abatuci@univ-angers.fr (Y.A.); \\ jean-jacques.helesbeux@univ-angers.fr (J.-J.H.) \\ * Correspondence: samuel.legeay@univ-angers.fr; Tel.: +33-(0)2-44-68-85-32
}

Received: 31 January 2020; Accepted: 26 February 2020; Published: 26 February 2020

\begin{abstract}
Polyphenols consumption has been associated with a lower risk of cardiovascular diseases (CVDs) notably through nitric oxide (NO)- and estrogen receptor $\alpha(\mathrm{ER} \alpha)$-dependent pathways. Among polyphenolic compounds, chalcones have been suggested to prevent endothelial dysfunction and hypertension. However, the involvement of both the NO and the ER $\alpha$ pathways for the beneficial vascular effects of chalcones has never been demonstrated. In this study, we aimed to identify chalcones with high vasorelaxation potential and to characterize the signaling pathways in relation to $\mathrm{ER} \alpha$ signaling and NO involvement. The evaluation of vasorelaxation potential was performed by myography on wild-type (WT) and $E R \alpha$ knock-out $(E R \alpha-K O)$ mice aorta in the presence or in absence of the eNOS inhibitor N $\omega$-nitro-L-arginine methyl ester (L-NAME). Among the set of chalcones that were synthesized, four $(3,8,13$ and 15) exhibited a strong vasorelaxant effect (more than $80 \%$ vasorelaxation) while five compounds $(\mathbf{6}, \mathbf{1 0}, \mathbf{1 1}, \mathbf{1 6}, \mathbf{1 7})$ have shown a $60 \%$ relief of the pre-contraction and four compounds $(\mathbf{1 2}, \mathbf{1 4}, \mathbf{1 8}, \mathbf{2 0})$ led to a lower vasorelaxation. We were able to demonstrate that the vasorelaxant effect of two highly active chalcones was either ER $\alpha$-dependent and NO-independent or ER $\alpha$-independent and NO-dependent. Thus some structure-activity relationships (SAR) were discussed for an optimized vasorelaxant effect.
\end{abstract}

Keywords: polyphenols; chalcones; structure-activity relationships; endothelium; vasodilation; cardiovascular diseases

\section{Introduction}

According to the World Health Organization (WHO), cardiovascular diseases are the first leading cause of death worldwide [1]. Most cardiovascular diseases (CVDs) are initially due to hypertension and/or atherosclerosis that could be initiated by endothelial dysfunction $[2,3]$. These pathological conditions lead to alterations of the endothelium resulting in imbalanced endothelial factors, including a decrease in nitric oxide (NO) bioavailability, vascular constriction, and platelet activation.

Interestingly, epidemiological studies indicate that the prevalence of CVDs is lower in premenopausal women compared to age-matched men and significantly increases in women after menopause, suggesting a protective role of estrogens in premenopausal women $[4,5]$. Both estrogen receptor $\alpha(E R \alpha)$ and estrogen receptor $\beta(E R \beta)$ are involved in cardiovascular protection with a predominant role of $\mathrm{ER} \alpha$ at the vascular level [6,7]. ER $\alpha$, expressed by endothelial cells and co-localized with endothelial NO synthase (eNOS), has been identified as an eNOS activator through an Src/ERK1/2-dependent pathway both in human primary endothelial cells and mice [8,9]. These 
endothelial effects are strengthened by clinical data reporting that menopausal hormone replacement therapy (MHT) prevents cardiovascular outcomes in perimenopausal women, confirming the role of estrogen receptor activation for the prevention of the endothelial dysfunction in women $[10,11]$.

Various studies have suggested that polyphenolic compounds consumption may prevent cardiovascular diseases [12-14]. Among polyphenols, chalcones, which belong to the flavonoid family and are ubiquitously found in fruits, vegetables, wine, and tea, have been described to favor vascular functions [15]. Recently, the chalcone isoliquiritigenin has been identified to induce an endothelium-independent vasodilation through a calcium-activated potassium channel-dependent $\left(\mathrm{BK}_{\mathrm{Ca}}\right)$ pathway in mice [15]. These results are not consistent with those obtained with dihydrospinochalcone-A which induced an endothelium-dependent vasodilation through a NO/sGC/PKG pathway [16]. Meanwhile, chalcones have been identified to exert an estrogenic activity notably through modulation of ER $\alpha$ [17]. Moreover, flavonoids-induced vasodilation through an ER $\alpha$ dependent pathway has already been observed both with rats and mice aortas $[8,9,18,19]$. However, the precise involvement of $\mathrm{ER} \alpha$ in the chalcones-induced vasodilation has not been studied so far.

The aim of this work was (i) to synthesize and characterize polyoxygenated chalcones, (ii) to evaluate their vasorelaxant potential on mice thoracic aorta, (iii) to assess the involvement of ER $\alpha$ and NO signaling pathways and (iv), to identify structure-activity relationships (SAR) for a high vasorelaxant efficacy and potency in order to complete the database of vasodilators which can be used for the prevention and/or the treatment of vascular diseases.

\section{Results}

\subsection{Chemistry and $\log P$}

Synthetic polyhydroxylated chalcones 3, 6, 8 and 10 were synthesized through a two-step procedure starting from the corresponding methoxymethyl (MOM)-protected acetophenones and benzaldehydes. Although this strategy required an extra deprotection step compared to Claisen-Schmidt condensation of phenolic starting materials, it has led to a better overall yield as observed for the synthesis of chalcone 8 compared to literature data $[20,21]$. Due to reactivity and efficiency issues in basic medium, chalcones 11, 13 and 17 bearing a hydroxyl $(\mathrm{OH})$ group in the C-4 position have been prepared through an acid-catalyzed coupling mechanism using thionyl chloride $\left(\mathrm{SOCl}_{2}\right)$ in ethanol $(\mathrm{EtOH})$. Thus it avoided the need for a synthesis strategy with a MOM protection-deprotection approach [22]. Nevertheless, in situ generated hydrochloric acid $(\mathrm{HCl})$ catalysis was unsuccessful when applied to the synthesis of diphenolic chalcone 18. Thus, it has been prepared under microwave (MW) irradiations in the presence of piperidine [23]. In this work two other synthetic chalcones $\mathbf{1 2}$ and 14, bearing a phenol function on the C-2, position, have been prepared through selective demethylation of the corresponding 2'-methoxychalcones $\mathbf{1 3}$ and $\mathbf{1 5}$ in the presence of aluminum chloride $\left(\mathrm{AlCl}_{3}\right)$ [24]. It is worth mentioning that the demethylation of hexamethoxychalcone $\mathbf{1 6}$ led only to $\mathbf{1 7}$ (52\% yield) without any trace of $\mathbf{1 8}$ (Scheme 1). Finally, the calculated octanol-water partition coefficient (cLogP) were similar, ranging from 1.80 for synthetic chalcone $\mathbf{6}$ to 3.33 for synthetic chalcone $\mathbf{1 4}$ (Table 1). 


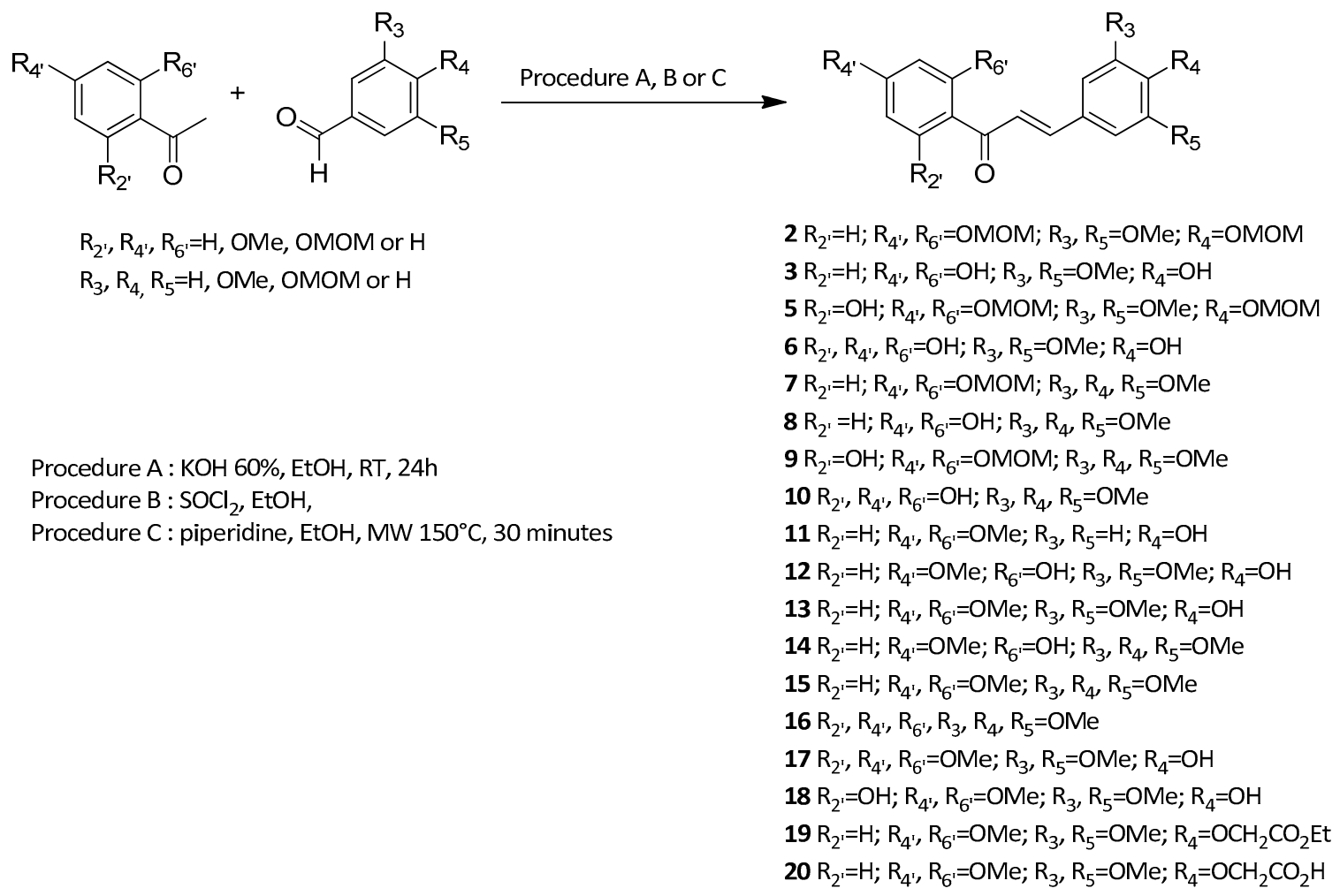

Scheme 1. General scheme for the synthesis of chalcones. Synthetic chalcones were synthesized through the coupling of the corresponding either MOM-protected or phenolic acetophenones and benzaldehydes. Hydrolysis of MOM groups or selective demethylation in the presence of $\mathrm{AlCl}_{3}$ were achieved. These procedures led to thirteen synthetic polyoxygenated chalcones whose vasorelaxant effect was evaluated.

Table 1. Synthesized chalcones and their related cLogP.<smiles>[R4]c1cc([R2])c(C(=O)/C=C/c2cc([R5])c([R4])c([R5])c2)c([R5])c1</smiles>

\begin{tabular}{|c|c|c|c|c|c|c|c|}
\hline Compound & $\mathrm{R}_{2^{\prime}}$ & $\mathrm{R}_{4^{\prime}}$ & $\mathrm{R}_{6^{\prime}}$ & $\mathrm{R}_{3}$ & $\mathrm{R}_{4}$ & $\mathrm{R}_{5}$ & $\operatorname{cLog} P$ \\
\hline 3 & $\mathrm{OH}$ & $\mathrm{OH}$ & $\mathrm{H}$ & $\mathrm{OCH}_{3}$ & $\mathrm{OH}$ & $\mathrm{OCH}_{3}$ & 2.42 \\
\hline 6 & $\mathrm{OH}$ & $\mathrm{OH}$ & $\mathrm{OH}$ & $\mathrm{OCH}_{3}$ & $\mathrm{OH}$ & $\mathrm{OCH}_{3}$ & 1.80 \\
\hline 8 & $\mathrm{OH}$ & $\mathrm{OH}$ & $\mathrm{H}$ & $\mathrm{OCH}_{3}$ & $\mathrm{OCH}_{3}$ & $\mathrm{OCH}_{3}$ & 2.75 \\
\hline 10 & $\mathrm{OH}$ & $\mathrm{OH}$ & $\mathrm{OH}$ & $\mathrm{OCH}_{3}$ & $\mathrm{OCH}_{3}$ & $\mathrm{OCH}_{3}$ & 2.13 \\
\hline 11 & $\mathrm{OCH}_{3}$ & $\mathrm{OCH}_{3}$ & $\mathrm{H}$ & $\mathrm{H}$ & $\mathrm{OH}$ & $\mathrm{H}$ & 3.20 \\
\hline 12 & $\mathrm{OH}$ & $\mathrm{OCH}_{3}$ & $\mathrm{H}$ & $\mathrm{OCH}_{3}$ & $\mathrm{OH}$ & $\mathrm{OCH}_{3}$ & 2.99 \\
\hline 13 & $\mathrm{OCH}_{3}$ & $\mathrm{OCH}_{3}$ & $\mathrm{H}$ & $\mathrm{OCH}_{3}$ & $\mathrm{OH}$ & $\mathrm{OCH}_{3}$ & 2.84 \\
\hline 14 & $\mathrm{OH}$ & $\mathrm{OCH}_{3}$ & $\mathrm{H}$ & $\mathrm{OCH}_{3}$ & $\mathrm{OCH}_{3}$ & $\mathrm{OCH}_{3}$ & 3.33 \\
\hline 15 & $\mathrm{OCH}_{3}$ & $\mathrm{OCH}_{3}$ & $\mathrm{H}$ & $\mathrm{OCH}_{3}$ & $\mathrm{OCH}_{3}$ & $\mathrm{OCH}_{3}$ & 3.17 \\
\hline 16 & $\mathrm{OCH}_{3}$ & $\mathrm{OCH}_{3}$ & $\mathrm{OCH}_{3}$ & $\mathrm{OCH}_{3}$ & $\mathrm{OCH}_{3}$ & $\mathrm{OCH}_{3}$ & 3.13 \\
\hline 17 & $\mathrm{OCH}_{3}$ & $\mathrm{OCH}_{3}$ & $\mathrm{OCH}_{3}$ & $\mathrm{OCH}_{3}$ & $\mathrm{OH}$ & $\mathrm{OCH}_{3}$ & 2.79 \\
\hline 18 & $\mathrm{OH}$ & $\mathrm{OCH}_{3}$ & $\mathrm{OCH}_{3}$ & $\mathrm{OCH}_{3}$ & $\mathrm{OH}$ & $\mathrm{OCH}_{3}$ & 2.97 \\
\hline 20 & $\mathrm{OCH}_{3}$ & $\mathrm{OCH}_{3}$ & $\mathrm{H}$ & $\mathrm{OCH}_{3}$ & $\mathrm{OCH}_{2} \mathrm{COOH}$ & $\mathrm{OCH}_{3}$ & 2.46 \\
\hline
\end{tabular}




\subsection{Evaluation of Vasorelaxant Activity}

Vasorelaxation induced by each synthetic chalcone was first evaluated on WT mice thoracic aorta rings. Compounds 3, 8, 13 and 15 with identical substituents at C-2' and C-4' positions, absence of substituent at the $\mathrm{C}-6^{\prime}$ position and presence of $\mathrm{OH}$ and/or $\mathrm{OCH}_{3}$ groups at $\mathrm{C}-3, \mathrm{C}-4$ and $\mathrm{C}-5$ positions induced a high vasorelaxation reaching more than $80 \%$. Compounds 6, 10, 11, 16 and 17 with $\mathrm{OH}$ or $\mathrm{OCH}_{3}$ group at the C- $6^{\prime}$ position or unsubstituted at $\mathrm{C}-3$ and $\mathrm{C}-5$ positions induced an average vasorelaxation between $50 \%$ to $80 \%$. Finally, compounds 12, 14, 18 and 20 with both $\mathrm{OH}$ and $\mathrm{OCH}_{3}$ groups at $\mathrm{C}-2^{\prime}, \mathrm{C}-4^{\prime}$ and/or $\mathrm{C}-6^{\prime}$ positions or a bulkier $\mathrm{OCH}_{2} \mathrm{COOH}$ group at $\mathrm{C}-3$ position exerted a low vasorelaxation effect below $50 \%$ (Figure 1 and Table 2).

A

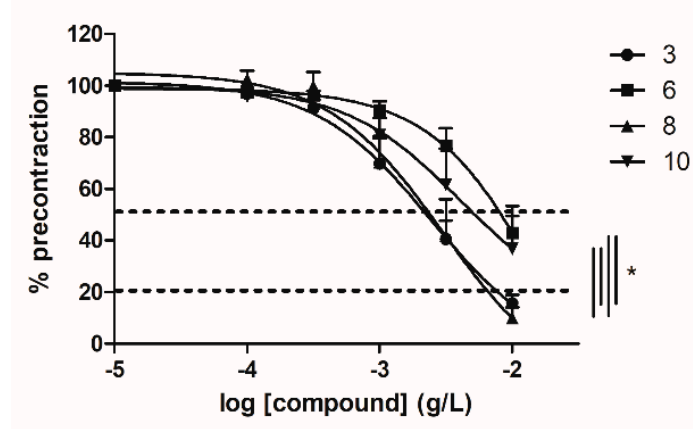

C

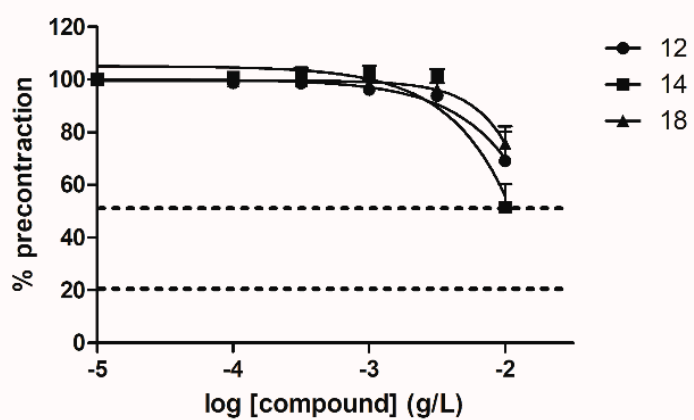

B

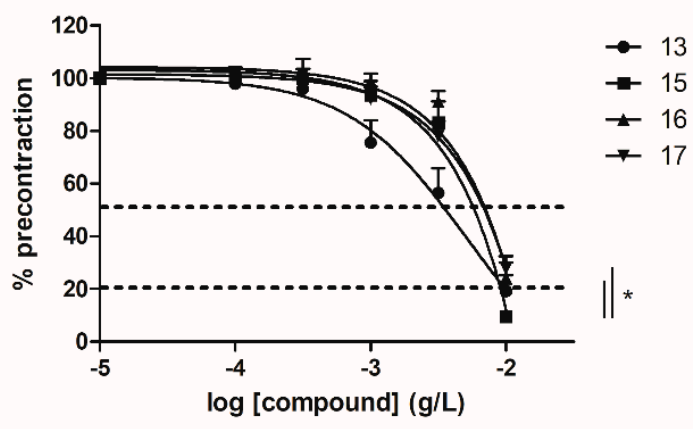

D

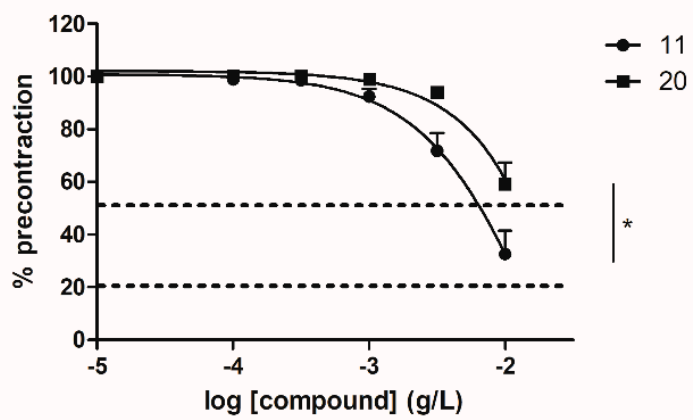

Figure 1. Concentration-response curves for the vasorelaxation effect on WT mice thoracic aorta of synthetic polyoxygenated chalcones. A: vasorelaxation effect of chalcones with $R_{2^{\prime}}=R_{4^{\prime}}=\mathrm{OH}$ and $\mathrm{R}_{6^{\prime}}=\mathrm{H}$ or OH; B: vasorelaxation effect of chalcones with $\mathrm{R}_{2^{\prime}}=\mathrm{R}_{4^{\prime}}=\mathrm{OCH}_{3}$ and $\mathrm{R}_{6^{\prime}}=\mathrm{H}$ or OCH $\mathrm{OCH}_{3} ; \mathrm{C}$ : vasorelaxation effect of chalcones with $\mathrm{R}_{2^{\prime}}=\mathrm{OH}, \mathrm{R}_{4^{\prime}}=\mathrm{OCH}_{3}$ and $\mathrm{R}_{6^{\prime}}=\mathrm{H}$ or $\mathrm{OCH}_{3}$; D: vasorelaxation effect of chalcones with $\mathrm{R}_{2^{\prime}}=\mathrm{R}_{4^{\prime}}=\mathrm{OCH}_{3}$ and $\mathrm{R}_{6^{\prime}}=\mathrm{H}$. Mice were ovariectomized 7 days before the experiment. Vessels were pre-contracted with U46619, phenylephrine, and serotonin, at $80 \%$ of their maximal response. The presence of functional endothelium was assessed by determining the ability of acetylcholine $(10 \mu \mathrm{M})$ to induce more than $50 \%$ relaxation of pre-contracted rings. Results are expressed in percentage of precontraction ( $y$-axis) following the concentration ( $x$-axis). Compounds 3, 8, 13 and 15 induced higher vasorelaxation, over $80 \%$. Compounds 6, 10, 11, 16 and 17 induced an average vasorelaxation between $50 \%$ to $80 \%$. Compounds 12, 14, 18 and 20 exerted a low vasorelaxation effect below $50 \% . N=4-7,{ }^{*} p<0.05$ (Mann-Whitney). 
Table 2. Summary of the potency and efficacy of chalcones.

\begin{tabular}{|c|c|c|c|c|c|}
\hline \multirow{2}{*}{ Compound } & \multirow{2}{*}{$\begin{array}{c}\text { Potency } \\
\left(\mathrm{EC}_{50}, \mathrm{~g} / \mathrm{L}\right) \\
\text { WT }\end{array}$} & \multicolumn{4}{|c|}{$\begin{array}{c}\text { Efficacy } \\
\left(E_{\max }, \%\right)\end{array}$} \\
\hline & & WT & $\begin{array}{l}\text { WT with } \\
\text { L-NAME }\end{array}$ & $\mathrm{ER} \alpha \mathrm{KO}$ & $\begin{array}{c}\text { ER } \alpha \text { KO with } \\
\text { L-NAME }\end{array}$ \\
\hline 3 & $2.44 \times 10^{-3}$ & $84.28 \pm 3.24^{\mathrm{a}, \mathrm{d}}$ & $77.62 \pm 4.92$ & $56.23 \pm 4.91^{£}$ & $43.22 \pm 6.10^{\$}$ \\
\hline 6 & $2.12 \times 10^{-3}$ & $57.10 \pm 10.40^{c, d}$ & $33.92 \pm 12.66$ & $60.69 \pm 10.75$ & $38.15 \pm 10.91$ \\
\hline 8 & $2.99 \times 10^{-3}$ & $89.96 \pm 4.13^{b, c}$ & $86.69 \pm 3.47$ & $79.73 \pm 3.71$ & $69.76 \pm 7.99$ \\
\hline 10 & $4.08 \times 10^{-3}$ & $63.29 \pm 12.79 a, b$ & $44.91 \pm 15.07$ & $52.83 \pm 12.88$ & $43.33 \pm 10.37$ \\
\hline 11 & $1.93 \times 10^{-2}$ & $67.35 \pm 8.94 \mathrm{~g}$ & $49.06 \pm 9.47$ & $74.81 \pm 2.07$ & $36.40 \pm 5.81$ \\
\hline 12 & NA & $30.95 \pm 13.23$ & NA & NA & NA \\
\hline 13 & $5.06 \times 10^{-2}$ & $80.86 \pm 6.11$ & $19.85 \pm 7.81$ * & $81.96 \pm 2.46$ & $26.96 \pm 6.72$ \\
\hline 14 & NA & $48.38 \pm 7.75$ & NA & $4.64 \pm 9.95$ & NA \\
\hline 15 & NA & $90.59 \pm 1.56^{\mathrm{e}, \mathrm{f}}$ & $76.07 \pm 3.72$ & $79.78 \pm 5.51$ & $76.74 \pm 5.68$ \\
\hline 16 & NA & $75.89 \pm 5.99^{f}$ & NA & $74.91 \pm 10.15$ & NA \\
\hline 17 & NA & $72.16 \pm 4.59^{\mathrm{e}}$ & NA & $86.88 \pm 4.40$ & NA \\
\hline 18 & NA & $24.34 \pm 4.60$ & NA & NA & NA \\
\hline 20 & NA & $40.77 \pm 8.22^{g}$ & NA & NA & NA \\
\hline
\end{tabular}

NA: Not Available. ${ }^{\mathrm{a}}(3$ vs. $10, p<0.05),{ }^{\mathrm{b}}(8$ vs. $10, p<0.05),{ }^{\mathrm{c}}(6$ vs. $8, p<0.05),{ }^{\mathrm{d}}(3$ vs. $6, p<0.05),{ }^{\mathrm{e}}(15$ vs. 17 , $p<0.05),{ }^{\mathrm{f}}(15$ vs. $16, p<0.05),{ }^{\mathrm{g}}$ (11 vs. $\left.20, p<0.05\right),{ }^{*}$ (WT vs. WT with L-NAME, $\left.p<0.05\right),{ }^{\mathrm{E}}$ (WT vs. ER $\alpha K O$, $p>0.01), \$(\mathrm{ER} \alpha \mathrm{KO}$ vs. ER $\alpha$ KO with L-NAME, $p<0.01)$.

\subsection{Involvement of ERa and NO Pathways}

\subsubsection{Evaluation of Vasorelaxant Activity on ER $\alpha$ KO Mice Aorta}

To evaluate the involvement of the ER $\alpha$ pathway in the chalcones-induced vasorelaxation, experiments have been conducted on $\mathrm{ER} \alpha \mathrm{KO}$ mice aortas. To focus on the role of $\mathrm{OH}$ or $\mathrm{OCH}_{3}$ groups at C-6' position with synthetic chalcones exhibiting a high vasorelaxant effect, compounds 3, 6, 8, 10, 13, 15, 16 and 17 have been tested on ER $\alpha \mathrm{KO}$ mice thoracic aorta rings. Interestingly, only the synthetic chalcone 3 induced a significant lower vasorelaxation in ER $\alpha$ KO mice thoracic aorta rings compared to WT mice thoracic aorta rings ( $56.23 \pm 4.91 \%$ vs. $84.28 \pm 3.24 \%$, respectively) while no significant differences were observed with synthetic chalcones 6, 8, 10, 13, 15, 16 and 17 (Figures 2 and 3 and Table 2). 
A

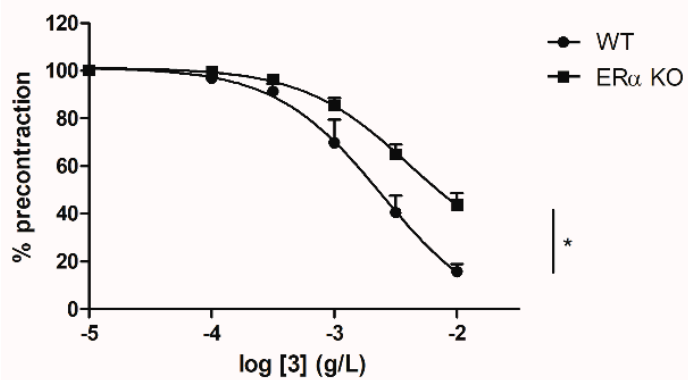

C

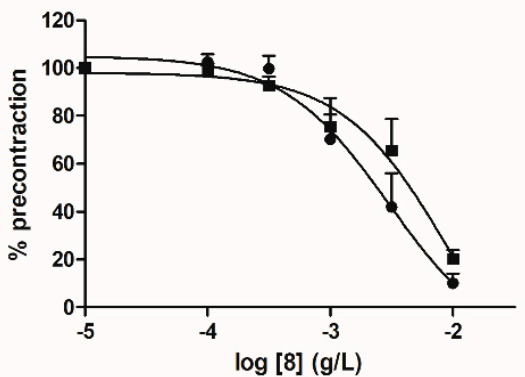

B

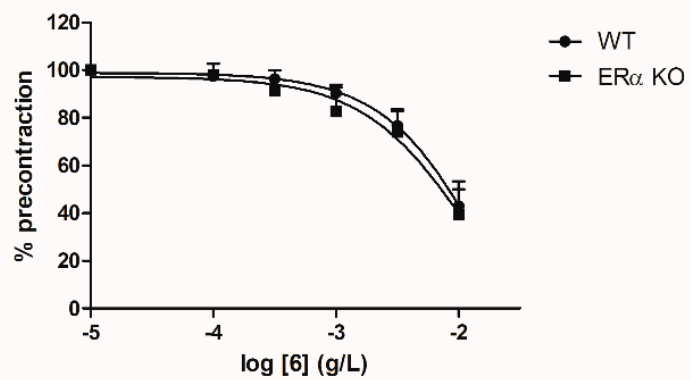

D

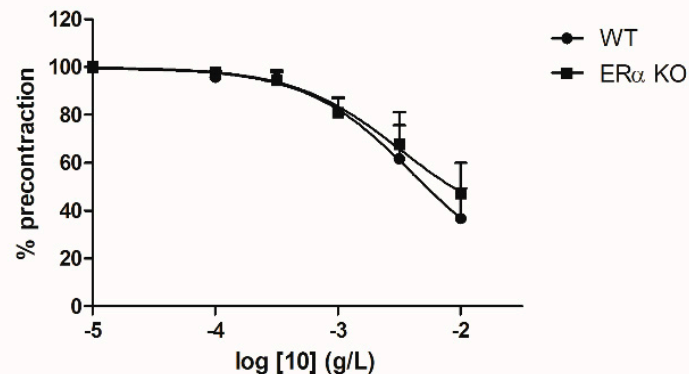

Figure 2. Concentration-response curves for the vasorelaxation effect on both WT and ER $\alpha$ KO mice thoracic aorta of synthetic chalcones $\mathbf{3}(\mathrm{A}), \mathbf{6}$ (B), 8 (C) and $\mathbf{1 0}$ (D). Mice were ovariectomized 7 days before the experiment. Vessels were pre-contracted with U46619, phenylephrine, and serotonin, at $80 \%$ of their maximal response. The presence of functional endothelium was assessed by determining the ability of acetylcholine $(10 \mu \mathrm{M})$ to induce more than $50 \%$ relaxation of pre-contracted rings. Results are expressed in percentage of precontraction ( $y$-axis) following the concentration ( $x$-axis). Only the synthetic chalcone 3 induced a significant lower vasorelaxation in ER $\alpha \mathrm{KO}$ mice thoracic aorta rings compared to WT mice thoracic aorta rings $(56.23 \pm 4.91 \%$ vs. $84.28 \pm 3.24 \%$ respectively) while no significant differences were observed with chalcones 6, 8 and 10. $N=4-7,{ }^{*} p<0.05$ (Mann-Whitney). 
A

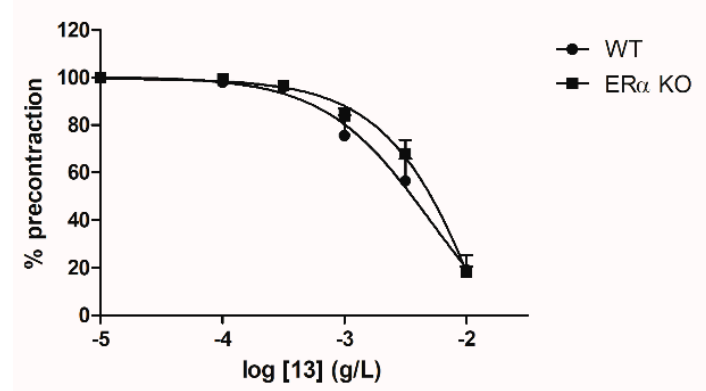

C

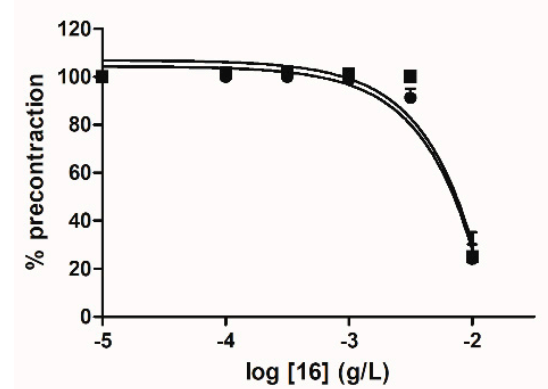

B

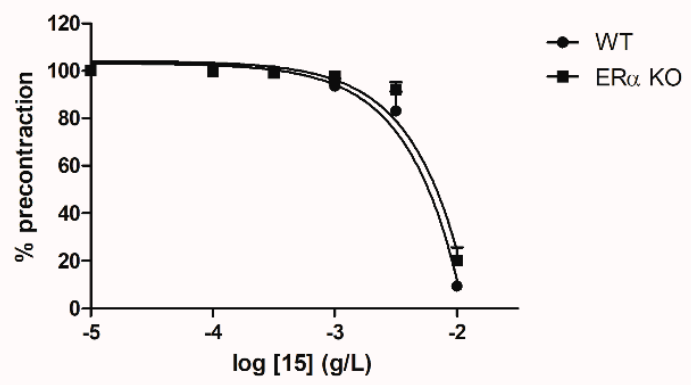

D

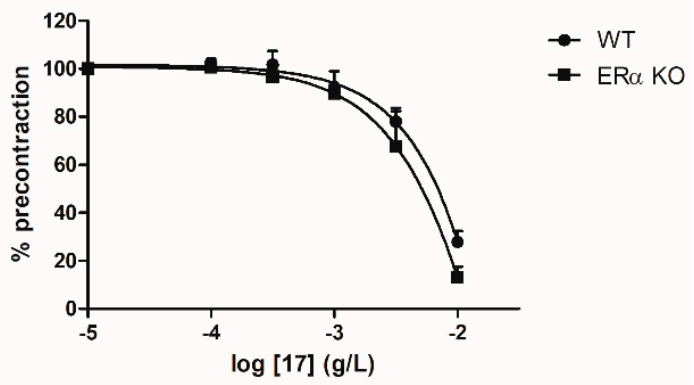

Figure 3. Concentration-response curves for the vasorelaxation effect on both WT and ER $\alpha \mathrm{KO}$ mice thoracic aorta of synthetic chalcones $\mathbf{1 3}$ (A), 15 (B), 16 (C) and 17 (D). Mice were ovariectomized 7 days before the experiment. Vessels were pre-contracted with U46619, phenylephrine, and serotonin, at $80 \%$ of their maximal response. The presence of functional endothelium was assessed by determining the ability of acetylcholine $(10 \mu \mathrm{M})$ to induce more than $50 \%$ relaxation of pre-contracted rings. Results are expressed in percentage of precontraction ( $y$-axis) following the concentration ( $x$-axis). No significant differences were observed with synthetic chalcones 13, 15, 16 and 17. $N=4-7$ (Mann-Whitney).

\subsubsection{Evaluation of Vasorelaxant Activity in the Presence of No-nitro-L-arginine methyl ester} (L-NAME)

In order to evaluate the involvement of the NO pathway, experiments have then been performed after incubation for 20 min with NOS inhibitor $\left(10^{-4} \mathrm{M}\right)$ on both WT and ER $\alpha$ KO mice thoracic aorta rings. To focus on the role of groups at C-2', C-4' and C-4 positions, synthetic chalcones 3, 8, 13 and 15 have been tested. Interestingly, L-NAME prevented the chalcone-induced vasorelaxation only for chalcone 13 in WT mice thoracic aorta rings at the highest concentration $\left(10^{-2} \mathrm{~g} / \mathrm{L}\right.$, Figure 4 and Table 2$)$. It is noteworthy that L-NAME seemed to prevent the chalcone-induced vasorelaxation for compounds 3 and 8 at low concentrations and this effect is not recovered at $10^{-2} \mathrm{~g} / \mathrm{L}$. No difference was observed for the synthetic chalcone 15 (Figure 4A,B). Similarly, the presence of L-NAME on ER $\alpha$ KO mice thoracic aorta rings prevented the vasorelaxation only with the synthetic chalcone $13(81.96 \pm 2.46 \%$ vs. $26.96 \pm$ $6.72 \%$ ) while having no effect with synthetic chalcones 3, 8 and 15 (Figure 5 and Table 2). 
A

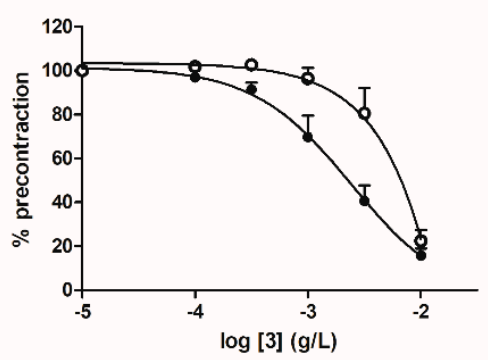

C

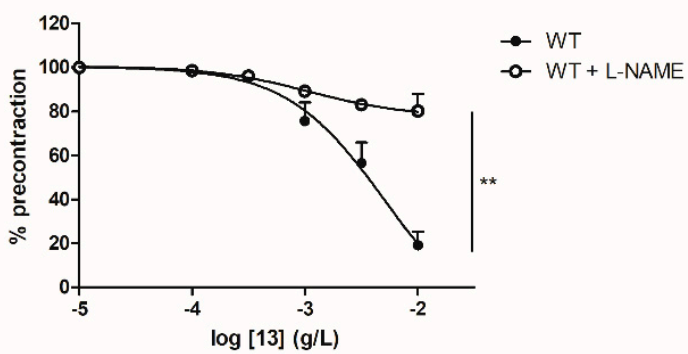

B

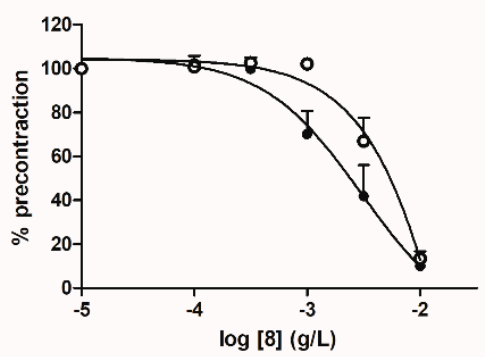

WT

- WT + L-NAME

D

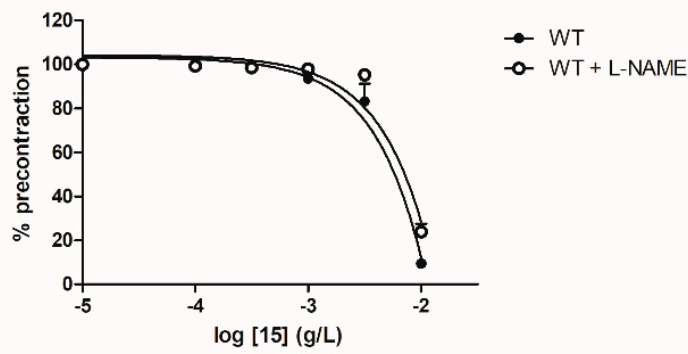

Figure 4. Concentration-response curves for the vasorelaxation effect on WT mice thoracic aorta of synthetic chalcones 3 (A), 8 (B), 13 (C) and 15 (D) in the presence or in absence of L-NAME, a selective eNOS inhibitor. Mice were ovariectomized 7 days before the experiment. Vessels were pre-contracted with U46619, phenylephrine, and serotonin, at $80 \%$ of their maximal response. The presence of functional endothelium was assessed by determining the ability of acetylcholine $(10 \mu \mathrm{M})$ to induce more than $50 \%$ relaxation of pre-contracted rings. Results are expressed in percentage of precontraction ( $y$-axis) following the concentration ( $x$-axis). L-NAME only prevented the chalcone-induced vasorelaxation for the synthetic chalcone 13 at the highest concentration $\left(10^{-2} \mathrm{~g} / \mathrm{L}\right)$ and seemed to prevent the chalcone-induced vasorelaxation for compounds $\mathbf{3}$ and $\mathbf{8}$ at low concentrations. No difference was observed for chalcone 15. $N=5-7,{ }^{* *} p<0.01$ (Mann-Whitney). 
A

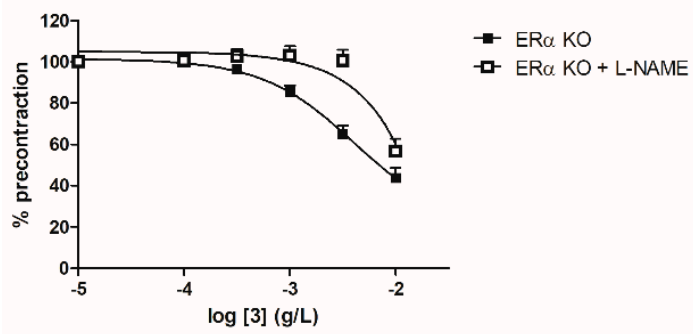

C

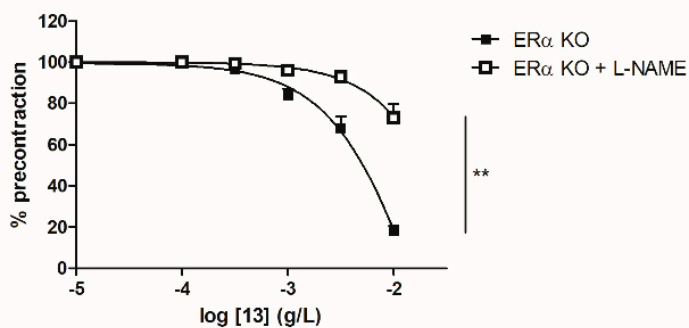

B

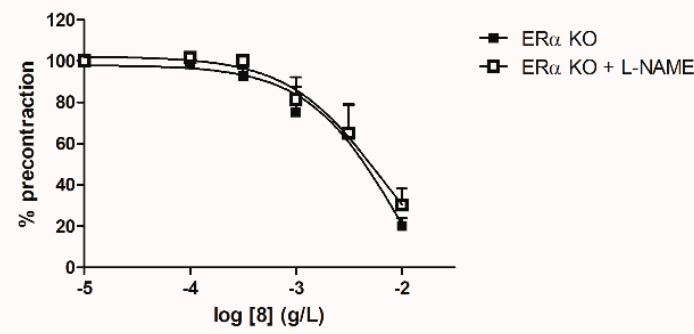

D

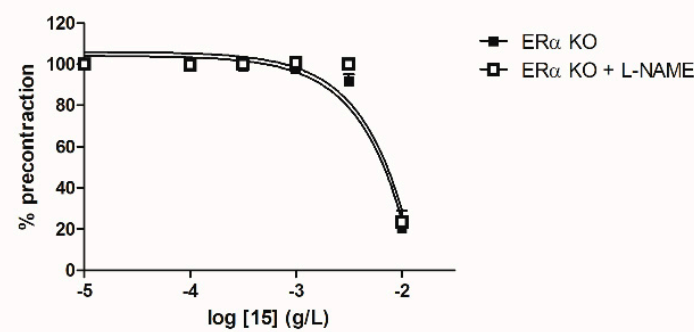

Figure 5. Concentration-response curves for the vasorelaxation effect on $\mathrm{ER} \alpha \mathrm{KO}$ mice thoracic aorta of synthetic chalcones 3 (A), 8 (B), 13 (C) and 15 (D). Mice were ovariectomized 7 days before the experiment. Vessels were pre-contracted with U46619, phenylephrine, and serotonin, at $80 \%$ of their maximal response. The presence of functional endothelium was assessed by determining the ability of acetylcholine $(10 \mu \mathrm{M})$ to induce more than $50 \%$ relaxation of pre-contracted rings. Results are expressed in percentage of precontraction ( $y$-axis) following the concentration ( $x$-axis). L-NAME only prevented the chalcone 13 -induced vasorelaxation $(81.96 \pm 2.46 \%$ vs. $26.96 \pm 6.72 \%)$ while having no effect with synthetic chalcones 3, 8 and 15. $N=4-7$, ** $p<0.01$ (Mann-Whitney).

\section{Discussion}

By inhibiting the angiotensin-converting enzyme (ACE) and inducing high vasodilation, the anti-hypertensive effect of amino-chalcones has been demonstrated in vitro and in vivo on rats, rabbits, and dogs [25,26]. Several molecular targets such as cyclooxygenase [27] and potassium channels [28], metabolism pathways such as triacylglycerol synthesis pathway [29-31] and pro-angiogenic properties [32] have also been identified to explain the potential role of chalcones in the prevention and/or treatment of cardiovascular diseases. However, all these effects have been mainly highlighted with functionalized chalcones bearing amino, prenyl or sulfonyloxy groups and little data are available for polyoxygenated chalcones [25].

The present study described the synthesis of thirteen synthetic chalcones bearing oxygenated substituents $\left(\mathrm{OH}\right.$ and $\left.\mathrm{OCH}_{3}\right)$. The pharmacological characterization of their vascular activity including the involvement of $\mathrm{NO}$ and $\mathrm{ER} \alpha$-dependent pathways allowed the identification of two promising compounds ( 3 and 13) inducing an endothelium-dependent vasorelaxation. Precisely, the synthetic chalcone 3 is preferable for an ER $\alpha$-dependent vasorelaxation while the synthetic chalcone $\mathbf{1 3}$ is preferable for an $\mathrm{ER} \alpha$-independent and NO-dependent vasorelaxation. 
$E R \alpha$ has already been identified as a target for chalcones, especially in the field of cancer $[17,33]$ and it is now well accepted that estrogens can protect against cardiovascular diseases $[11,34,35]$. At the vascular level, ER $\alpha$ pathway can, through a non-genomic mechanism, lead to an endothelium-dependent vasodilation [34,36]. The identification in this work of compounds $\mathbf{3}$ and $\mathbf{1 3}$ with an ER $\alpha$ - or NO-dependent mechanism, respectively, clearly confirms that these two chalcones exert an endothelium-dependent vasorelaxation in mice thoracic aorta.

Other vascular mechanisms as phosphodiesterase (PDE) inhibition or calcium channel blocking have also been described to disclose chalcones-induced vasorelaxation $[9,15]$. These targets, mainly located on vascular smooth muscle cells, would explain the NO- and ER $\alpha$-independent vasorelaxation of the other synthetic chalcones tested. In addition, these mechanisms may also be involved to explain the remaining vasorelaxation observed on ER $\alpha \mathrm{KO}$ mice in the presence of L-NAME. Further studies are however required to confirm the involvement of PDE or calcium channel in the NO- and ER $\alpha$-independent vasorelaxation of the present synthetic chalcones.

Modifications of the substitution pattern contributed to the study of structure-activity relationships. The synthetic chalcone 14, bearing an $\mathrm{OH}$ group at $\mathrm{C}-2^{\prime}$ position and an $\mathrm{OCH}_{3}$ group at $\mathrm{C}-4^{\prime}$ position exerted a low vasorelaxation effect (less than 50\%). Synthetic chalcones 6, 10, 16, 17 and 18, bearing an $\mathrm{OH}$ group or an $\mathrm{OCH}_{3}$ group at the C-6' position, exerted an average or a low vasorelaxation effect (less than $80 \%$ ). Altogether, the data collected here demonstrated that both C-2' and C-4' positions must bear the same group, either $\mathrm{OH}$ or $\mathrm{OCH}_{3}$, and an unsubstituted C-6' position is required for a better activity. Accordingly, in a study evaluating the relaxant potency and efficacy in rat thoracic aorta of prenylated and allylated chalcones, an increased vasorelaxant efficacy was also identified for chalcones without any $\mathrm{OH}$ group at the $\mathrm{C}^{6} 6^{\prime}$ position [37]. Additionally, the number of $\mathrm{OH}$ groups bearing by the chalcone backbone was also described as an important factor for a higher activity [37]. The replacement of $\mathrm{OH}$ groups by $\mathrm{OCH}_{3}$ groups revealed that the corresponding compounds did not exhibit a higher relaxant efficacy as demonstrated with compound 3 and 8 compared to compound 13 and $\mathbf{1 5}$. These data confirmed the importance of the number of $\mathrm{OH}$ groups but they also highlighted that $\mathrm{OCH}_{3}$ groups must be considered. More precisely, we identified that the 3,5-dimethoxy-4-hydroxybenzene moiety is required for both an ER $\alpha$ - or NO-dependent vasorelaxation in both $2^{\prime}, 4^{\prime}$-dihydroxychalcone or 2', 4'-dimethoxychalcone series.

Recently, isoliquiritigenin has been described to induce an endothelium-independent vasodilation through a calcium-activated potassium channel-dependent $\left(\mathrm{BK}_{\mathrm{Ca}}\right)$ pathway in mice [15]. By substituting $\mathrm{OH}$ groups by $\mathrm{OCH}_{3}$ groups at the $\mathrm{C}-2^{\prime}$ and $\mathrm{C}-4^{\prime}$ positions, isoliquiritigenin derivatives such as compound $\mathbf{1 1}$ have been synthsized. This synthetic chalcone exerted a comparable vasorelaxation than isoliquiritigenin through an endothelium-independent pathway. The involvement of the $\mathrm{BK}_{\mathrm{Ca}}$ in compound 11-induced vasorelaxation now needs to be explored in order to further understand the role of the methoxylation at $\mathrm{C}-2^{\prime}$ and $\mathrm{C}^{-4} 4^{\prime}$ positions in the $\mathrm{BK}_{\mathrm{Ca}}$-dependent vasorelaxation.

Similar cLogP, ranging from 1.80 to 3.33 were observed for the thirteen synthesized chalcones. We and others demonstrated that a higher cLogP value of flavonoids was associated with a higher vasorelaxation potential $[9,38]$. However, this association has been observed for flavonoids with very low lipophilicity (cLogP < 1) as anthocyanidins [9]. In the present study, no association between cLogP and the vasorelaxant potential has been observed, likely because of cLogP mainly ranging around 2 and 3.

In conclusion, coupling reactions between acetophenones and benzaldehydes led to thirteen synthetic polyoxygenated chalcones bearing $\mathrm{OH}$ groups and/or $\mathrm{OCH}_{3}$ groups and/or a bulkier $\mathrm{OCH}_{2} \mathrm{COOH}$ group. The vascular effects of chalcones were assessed on WT and $\mathrm{ER} \alpha \mathrm{KO}$ mice thoracic aorta and revealed four compounds with a very high vasorelaxation potential $(3,8,13$ and 15). More precisely, the synthetic chalcone 3 exerted an ER $\alpha$-dependent and NO-independent vasorelaxation while the synthetic chalcone 13 exerted an ER $\alpha$-independent and NO-dependent vasorelaxation. Structure-activity relationships (SAR) study allowed us to identify the 3,5-dimethoxy-4-hydroxybenzene moiety as a pharmacophore for both an $\mathrm{ER} \alpha$ - or NO-dependent vasorelaxation. Finally, the current 
study provides new promising data for the preventive and therapeutic use of chalcones in the field of CVDs.

\section{Materials and Methods}

\subsection{Chemistry}

All chemicals were purchased from Acros Organics (Geel, Belgium). Chromatographic separations for purification processes were achieved with flash chromatography IntelliFlash 310 (Analogix) using pre-packed C18 (Interchim) or silica gel column Chromabond®flash RS column (Macherey-Nagel). ${ }^{1} \mathrm{H}$ and ${ }^{13} \mathrm{C}$ NMR were recorded on Jeol GSX WB 270MHz. Chemical shifts are reported in parts per million ( $\delta \mathrm{ppm})$.

Different procedures (A, B or C) have been used to achieve the Claisen Schmidt condensation (Scheme 2).<smiles>[R]c1cc(OC)cc(OC)c1C(=O)Oc1cc(OC)c(OC)c(OC)c1</smiles>

Scheme 2. Strategy for Procedure A.

Procedure A: To a solution of acetophenone $(0.5 \mathrm{mmol})$ in ethanol are added benzaldehyde $(0.5$ $\mathrm{mmol}$ ) and a $60 \%$ solution of potassium hydroxide $(\mathrm{KOH})$. The resulting reaction mixture is stirred at room temperature for $24 \mathrm{H}$. Then $10 \mathrm{~mL}$ of water is added. The corresponding chalcone is collected by vacuum filtration or purified by silica gel flash chromatography. When MOM protecting groups are used, their hydrolysis is undertaken with $2 \mathrm{~N} \mathrm{HCl}$ (2 eq/MOM group) at reflux in a methanol solution. Completion of the reaction is determined by thin-layer chromatography (TLC). After cooling at room temperature (RT), water is added to the reaction mixture and the chalcone is extracted three times with ethyl acetate (EtOAc). The final product is purified by column chromatography.

(E)-1-(2,4-dimethoxymethylphenyl)-3-(4-methoxymethyl-3,5-dimethoxyphenyl)prop-2-en-1-one (2). Procedure A was applied starting from $226 \mathrm{mg}$ of 4-methoxymethyl-3,5-dimethoxybenzaldehyde (1 mmol) and $240 \mathrm{mg}$ (1 mmol) of 2,4-dimethoxymethylacetophenone. Yield: $63 \% .{ }^{1} \mathrm{H} \mathrm{NMR}\left(270 \mathrm{MHz}, \mathrm{CDCl}_{3}\right): \delta$ $7.64(\mathrm{~d}, J=8.6 \mathrm{~Hz}, 1 \mathrm{H}), 7.54(\mathrm{~d}, J=15.7 \mathrm{~Hz}, 1 \mathrm{H}), 7.34(\mathrm{~d}, J=15.7 \mathrm{~Hz}, 1 \mathrm{H}), 6.82(\mathrm{~m}, 3 \mathrm{H}), 6.76(\mathrm{~d}, J=8.6$ $\mathrm{Hz}, 1 \mathrm{H}), 5.24(\mathrm{~s}, 2 \mathrm{H}), 5.21(\mathrm{~s}, 2 \mathrm{H}), 5.16(\mathrm{~s}, 2 \mathrm{H}), 3.87(\mathrm{~s}, 3 \mathrm{H}), 3.60(\mathrm{~s}, 3 \mathrm{H}), 3.49(\mathrm{~s}, 3 \mathrm{H}) .{ }^{13} \mathrm{C} \mathrm{NMR}(68 \mathrm{MHz}$, $\left.\mathrm{CDCl}_{3}\right): \delta 191.1,161.3,157.4,153.6,142.7,136.5,132.1,131.2,126.6,124.0,109.2,105.4,103.5,98.2,95.1$, $94.2,57.1,56.5,56.2,56.0$. 
(E)-1-(2,4-dihydroxyphenyl)-3-(4-hydroxy-3,5-dimethoxyphenyl)prop-2-en-1-one (3). Hydrolysis was performed starting from $2(83 \mathrm{mg}, 0.18 \mathrm{mmol})$ leading to $18 \mathrm{mg}$ of 3 . Yield: $30 \%$. ${ }^{1} \mathrm{H} \mathrm{NMR}$ $\left(270 \mathrm{MHz}, \mathrm{CD}_{3} \mathrm{OD}\right): \delta 8.06(\mathrm{~d}, J=9.0 \mathrm{~Hz}, 1 \mathrm{H}), 7.78(\mathrm{~d}, J=15.2 \mathrm{~Hz}, 1 \mathrm{H}), 7.68(\mathrm{~d}, J=15.4 \mathrm{~Hz}, 1 \mathrm{H}), 7.08(\mathrm{~s}$, $2 \mathrm{H}), 6.41(\mathrm{dd}, J=8.9,2.4 \mathrm{~Hz}, 1 \mathrm{H}), 6.29(\mathrm{~d}, J=2.4 \mathrm{~Hz}, 1 \mathrm{H}), 3.93(\mathrm{~s}, 3 \mathrm{H}) .{ }^{13} \mathrm{C} \mathrm{NMR}\left(68 \mathrm{MHz}, \mathrm{CD}_{3} \mathrm{OD}\right)$ : $\delta 194.6,168.6,167.4,150.6,147.2,141.0,134.6,128.4,120.1,115.8,110.1,108.6,104.7,57.9$.

(E)-1-(2-hydroxy-4,6-dimethoxymethylphenyl)-3-(4-methoxymethyl-3,5-dimethoxyphenyl)prop-2-en-1-one (5). Procedure A was applied starting from $256 \mathrm{mg}$ of 2-hydroxy-4,6-dimethoxymethylacetophenone (1 mmol) and $226 \mathrm{mg}$ of 4-methoxymethyl-3,5-dimethoxybenzaldehyde (1 mmol). Yield: $92 \% .{ }^{1} \mathrm{H}$ $\operatorname{NMR}\left(270 \mathrm{MHz}, \mathrm{CDCl}_{3}\right): \delta 7.86(\mathrm{~d}, J=15.5 \mathrm{~Hz}, 1 \mathrm{H}), 7.71(\mathrm{~d}, J=15.5 \mathrm{~Hz}, 1 \mathrm{H}), 6.85(\mathrm{~s}, 2 \mathrm{H}), 6.32(\mathrm{~d}, J=$ $2.3 \mathrm{~Hz}, 1 \mathrm{H}), 6.21(\mathrm{~d}, J=2.3 \mathrm{~Hz}, 1 \mathrm{H}), 5.28(\mathrm{~s}, 2 \mathrm{H}), 5.20(\mathrm{~s}, 2 \mathrm{H}), 5.18(\mathrm{~s}, 6 \mathrm{H}), 3.62(\mathrm{~s}), 3.54(\mathrm{~s}), 3.49(\mathrm{~s}) .{ }^{13} \mathrm{C}$ NMR $\left(68 \mathrm{MHz} \mathrm{CDCl}_{3}\right): \delta 192.8,167.4,163.6,159.9,153.7,142.6,131.5,126.9,107.6,105.5,98.3,97.6$, 95.4, 94.7, 94.0, 57.2, 57.0, 56.5, 56.0.

(E)-1-(2,4,6-trihydroxyphenyl)-3-(4-hydroxy-3,5-dimethoxyphenyl)prop-2-en-1-one (6). Hydrolysis was performed starting from $5(141 \mathrm{mg}, 0.30 \mathrm{mmol})$ leading to $28 \mathrm{mg}$ of 6 . Yield: $28 \%$. ${ }^{1} \mathrm{H} \mathrm{NMR}(270 \mathrm{MHz}$, $\delta 8.08(\mathrm{~d}, J=15.5 \mathrm{~Hz}, 1 \mathrm{H}), 7.67(\mathrm{~d}, J=15.5 \mathrm{~Hz}, 1 \mathrm{H}), 6.93(\mathrm{~s}, 2 \mathrm{H}), 5.84(\mathrm{~s}, 2 \mathrm{H}), 3.89(\mathrm{~s}, 6 \mathrm{H}) .{ }^{13} \mathrm{C} \mathrm{NMR}$ (68 MHz, CD $\left.{ }_{3} \mathrm{OD}\right): \delta 195.0,167.2,166.9,150.6,144.9,140.5,129.0,127.3,108.0,106.9,97.0,57.7$.

(E)-1-(2,4-dimethoxymethylphenyl)-3-(3,4,5-trimethoxyphenyl)prop-2-en-1-one (7). Procedure A was applied, starting from $196 \mathrm{mg}(1 \mathrm{mmol})$ of 3,4,5-trimethoxybenzaldehyde and $240 \mathrm{mg}(1 \mathrm{mmol})$ of 2,4-dimethoxymethylacetophenone. Yield: $49 \%$.

(E)-1-(2,4-dihydroxyphenyl)-3-(3,4,5-trimethoxyphenyl)prop-2-en-1-one (8). Hydrolysis was performed starting from 7 (100 mg, $0.24 \mathrm{mmol})$ leading to $77 \mathrm{mg}$ of 8 . Yield: $97 \%$. ${ }^{1} \mathrm{H} \mathrm{NMR}\left(270 \mathrm{MHz}, \mathrm{CD}_{3} \mathrm{OD}\right): \delta$ $8.07(\mathrm{~d}, J=9.0 \mathrm{~Hz}, 1 \mathrm{H}), 7.77(\mathrm{~s}, 2 \mathrm{H}), 7.09(\mathrm{~s}, 2 \mathrm{H}), 6.43(\mathrm{dd}, J=8.8,2.4 \mathrm{~Hz}, 1 \mathrm{H}), 6.30(\mathrm{~d}, J=2.4 \mathrm{~Hz}, 1 \mathrm{H})$, $3.92(\mathrm{~s}, 6 \mathrm{H}), 3.82(\mathrm{~s}, 3 \mathrm{H})$.

(E)-1-(2-hydroxy-4,6-dimethoxymethylphenyl)-3-(3,4,5-trimethoxyphenyl)prop-2-en-1-one (9). Procedure A was applied starting from $105 \mathrm{mg}$ of 3,4,5-trimethoxybenzaldehyde( $0.53 \mathrm{mmol})$ and $137 \mathrm{mg}$ of 2-hydroxy-4,6-dimethoxymethylacetophenone(0.53 mmol). Yield: $62 \%$.

(E)-1-(2,4,6-trihydroxyphenyl)-3-(3,4,5-trimethoxyphenyl)prop-2-en-1-one (10). Hydrolysis was performed starting from 9 (80 mg, $0.18 \mathrm{mmol})$ leading to $59 \mathrm{mg}$ of 10. Yield: $92 \%$. ${ }^{1} \mathrm{H} \mathrm{NMR}\left(270 \mathrm{MHz}, \mathrm{CD}_{3} \mathrm{OD}\right): \delta$ $8.13(\mathrm{~d}, J=15.5 \mathrm{~Hz}, 1 \mathrm{H}), 7.66(\mathrm{~d}, J=15.6 \mathrm{~Hz}, 1 \mathrm{H}), 6.94(\mathrm{~s}, 2 \mathrm{H}), 5.85(\mathrm{~s}, 2 \mathrm{H}), 3.89(\mathrm{~s}, 6 \mathrm{H}), 3.81(\mathrm{~s}, 3 \mathrm{H})$. ${ }^{13} \mathrm{C}$ NMR $\left(68 \mathrm{MHz}, \mathrm{CD}_{3} \mathrm{OD}\right) \delta 195.0,167.5,167.0,155.8,143.9,142.1,134.0,129.5,107.8,107.0,97.0$, 62.1, 57.6.

(E)-1-(2,4-dimethoxyphenyl)-3-(3,4,5-trimethoxyphenyl)prop-2-en-1-one (15). Procedure A has been applied using $200 \mathrm{mg}(1.11 \mathrm{mmol})$ of 2,4-dimethoxyacetophenone and $220 \mathrm{mg}(1.11 \mathrm{mmol})$ of 3,4,5-trimethoxybenzaldehyde leading to $275 \mathrm{mg}$ of 15 as a yellow powder (69\% yield). ${ }^{1} \mathrm{H} \mathrm{NMR}$ $\left(\mathrm{CDCl}_{3}, 270 \mathrm{MHz}\right): \delta 7.73(\mathrm{~d}, 1 \mathrm{H}, J=8.6 \mathrm{~Hz}), 7.57(\mathrm{~d}, 1 \mathrm{H}, J=15.7 \mathrm{~Hz}), 7.37(\mathrm{~d}, 1 \mathrm{H}, J=15.7 \mathrm{~Hz}), 6.82(\mathrm{~s}$, $2 \mathrm{H}), 6.57(\mathrm{dd}, 1 \mathrm{H}, J=8.4 \mathrm{~Hz}, J=2.2 \mathrm{~Hz}), 6.51(\mathrm{~d}, 1 \mathrm{H}, J=2.4 \mathrm{~Hz}) .{ }^{13} \mathrm{C} \mathrm{NMR}\left(\mathrm{CDCl}_{3}, 68 \mathrm{MHz}\right): \delta 194.8$, 162.6, 159.1, 151.5, 149.5, 144.9, 128.3, 127.6, 123.2, 112.2, 111.3, 110.3, 91.1, 56.2, 56.2, 56.1, 55.7.HRMS $\mathrm{FAB}[\mathrm{M}+\mathrm{H}] 359.1483$.

(E)-1-(2,4,6-trimethoxyphenyl)-3-(3,4,5-trimethoxyphenyl)prop-2-en-1-one (16). Procedure A has been applied using $100 \mathrm{mg}$ of 2,4,6-trimethoxyacetophenone and $93 \mathrm{mg}$ of 3,4,5-trimethoxybenzaldehyde leading to $125 \mathrm{mg}$ of 16 as a light yellow powder (72\% yield). ${ }^{1} \mathrm{H} \mathrm{NMR}\left(\mathrm{CDCl}_{3}, 270 \mathrm{MHz}\right): \delta 7.24(\mathrm{~d}$, $1 \mathrm{H}, J=15.9 \mathrm{H}), 6.86(\mathrm{~d}, 1 \mathrm{H}, J=15.9 \mathrm{~Hz}), 6.75(\mathrm{~s}, 2 \mathrm{H}), 6.17(\mathrm{~s}, 2 \mathrm{H}), 3.87(\mathrm{~s}, 9 \mathrm{H}), 3.86(\mathrm{~s}, 3 \mathrm{H}), 3,77(\mathrm{~s}, 6 \mathrm{H})$. ${ }^{13} \mathrm{C} \mathrm{NMR}\left(\mathrm{CDCl}_{3}, 68 \mathrm{MHz}\right): \delta 194.6,162.6,159.0,153.6,144.6,140.3,130.7,128.8,112.0,105.7,90.9,61.1$, 56.3, 56.1, 55.6. HRMS FAB [M + H] 389.1589.

Procedure B: Thionyl chloride (0.5 eq) is added dropwise to a solution of acetophenone (1 eq) and benzaldehyde $(1 \mathrm{eq})$ in $3 \mathrm{~mL}$ of dichloromethane (DCM). After being stirred at room temperature 
for $24 \mathrm{~h}$, the reaction mixture is quenched with $10 \mathrm{~mL}$ of water. Crude chalcone is collected through filtration and could be purified by silica gel column chromatography when it is required.

(E)-3-(4-hydroxyphenyl)-1-(2,4-dimethoxyphenyl)prop-2-en-1-one (11). Procedure B was applied starting from $149 \mathrm{mg}$ of 2,4-dimethoxyacetophenone and $101 \mathrm{mg}$ of 4-hydroxybenzaldehyde, leading to $184 \mathrm{mg}$ of $\mathbf{1 1}$ as a greenish powder. Yield: $78 \% .{ }^{1} \mathrm{H} \mathrm{NMR}\left(\mathrm{CDCl}_{3}, 270 \mathrm{MHz}\right): \delta 7.73(\mathrm{~d}, J=8.5 \mathrm{~Hz}, 1 \mathrm{H}), 7.64(\mathrm{~d}$, $1 \mathrm{H}, J=15.6 \mathrm{~Hz}$, oléfine), $7.48(\mathrm{~d}, 2 \mathrm{H}, J=8.5 \mathrm{~Hz}, \mathrm{Ar}), 7.37(\mathrm{~d}, 1 \mathrm{H}, J=15.6 \mathrm{~Hz}$, oléfine), $6.88(\mathrm{~d}, 2 \mathrm{H}, J=$ $8.5 \mathrm{~Hz}, \mathrm{Ar}), 6.78(\mathrm{~s}, 1 \mathrm{H}, \mathrm{OH}), 6.56(\mathrm{dd}, 1 \mathrm{H}, J=8.7 \mathrm{~Hz}, 2.0 \mathrm{~Hz}, \mathrm{Ar}), 6.49(\mathrm{~d}, 1 \mathrm{H}, J=2.1 \mathrm{~Hz}, \mathrm{Ar}), 3.89$ (s, $3 \mathrm{H},-\mathrm{OMe}), 3.87$ (s,3H,-OMe). 13C RMN (CDCl3, $68 \mathrm{MHz}): \delta 191.7,164.5,160.7,158.5,143.2,133.1$, $130.6,128.1,124.9,122.6,116.3,105.5,105.4,99.0,56.0,55.8$.

(E)-3-(4-hydroxy-3,5-dimethoxyphenyl)-1-(2,4-dimethoxyphenyl)prop-2-en-1-one (13). Procedure B was applied starting from $250 \mathrm{mg}$ of 2,4-dimethoxyacetophenone and $250 \mathrm{mg}$ of 4-hydroxy-3,5-dimethoxybenzaldehyde, leading, after column chromatography (cyclohexane-EtOAc (6:4)) to $394 \mathrm{mg}$ of 13 as a yellow oil. Yield: $85 \% .{ }^{1} \mathrm{H} \mathrm{NMR}\left(\mathrm{CDCl}_{3}, 270 \mathrm{MHz}\right): \delta 7.71(\mathrm{~d}, J=8.5 \mathrm{~Hz}, 1 \mathrm{H})$, $7.57(\mathrm{~d}, J=15.7 \mathrm{~Hz}, 1 \mathrm{H}), 7.32(\mathrm{~d}, J=15.6 \mathrm{~Hz}, 1 \mathrm{H}), 6.57(\mathrm{dd}, J=8.6 \mathrm{~Hz}, 2.3 \mathrm{~Hz}, 1 \mathrm{H}), 6.50(\mathrm{~d}, J=2.2 \mathrm{~Hz}$, 1H), $5.79(\mathrm{~s}, 1 \mathrm{H}), 3.93(\mathrm{~s}, 6 \mathrm{H}), 3.90(\mathrm{~s}, 3 \mathrm{H}), 3.88(\mathrm{~s}, 3 \mathrm{H}) .{ }^{13} \mathrm{C} \mathrm{RMN}\left(\mathrm{CDCl}_{3}, 68 \mathrm{MHz}\right): \delta 191.0,164.2,160.4$, $147.4,143.1,137.2,132.8,127.1,125.6,122.6,105.5,105.3,98.9,56.5,55.9,55.7$.

(E)-3-(4-hydroxy-3,5-dimethoxyphenyl)-1-(2,4,6-trimethoxyphenyl)prop-2-en-1-one (17). Procedure B was applied starting from $150 \mathrm{mg}$ of 2,4,6-trimethoxyacetophenone and $129 \mathrm{mg}$ of 4-hydroxy-3,5-dimethoxybenzaldehyde, leading to $70 \mathrm{mg}$ of $\mathbf{1 7}$ as a yellow powder. Yield: $26 \%$. ${ }^{1} \mathrm{H}$ NMR $\left(\mathrm{CDCl}_{3}, 270 \mathrm{MHz}\right): \delta 7.23(\mathrm{~d}, J=15.7 \mathrm{~Hz}, 1 \mathrm{H}), 6.83(\mathrm{~d}, J=15.9 \mathrm{~Hz}, 1 \mathrm{H}), 6.76(\mathrm{~s}, 2 \mathrm{H}, \mathrm{Ar}), 6.17(\mathrm{~s}$, 2H), $\left.5.79(\mathrm{~s}, 1 \mathrm{H}), 3.90(\mathrm{~s}, 6 \mathrm{H}), 3.87(\mathrm{~s}, 3 \mathrm{H}), 3.77(\mathrm{~s}, 6 \mathrm{H}) .{ }^{13} \mathrm{C} \mathrm{NMR}_{\left(\mathrm{CDCl}^{3},\right.}, 68 \mathrm{MHz}\right): \delta 194.8,162.6,159.1$, $147.5,145.3,137.5,127.6,126.8,112.2,105.6,91.0,56.6,56.2,55.7$. HRMS FAB [M + H] 389.1589.

Procedure C: In a dry reactor, $150 \mathrm{mg}(0,76 \mathrm{mmol})$ of 2-hydroxy-4,6-dimethoxyacetophenone and $139 \mathrm{mg}$ of 4-hydroxy-3,5-dimethoxybenzaldehyde are dissolved in ethanol (4 mL) with $200 \mu \mathrm{L}$ of piperidine. The reaction mixture is then heated at $150^{\circ} \mathrm{C}$ for 30 minutes in a Milestone microwave. After cooling at room temperature, the suspension is filtered under reduced pressure leading to $74 \mathrm{mg}$ of the expected chalcone 18 (yield: $27 \%$ ).

(E)-3-(4-hydroxy-3,5-dimethoxyphenyl)-1-(2-hydroxy-4,6-dimethoxyphenyl)prop-2-en-1-one (18). ${ }^{1} \mathrm{H}$ NMR $\left(\mathrm{CDCl}_{3}, 270 \mathrm{MHz}\right): \delta 14.39(\mathrm{~s}, 1 \mathrm{H}), 7.78(\mathrm{~d}, J=15.4 \mathrm{~Hz}, 1 \mathrm{H}), 7.71(\mathrm{~d}, J=15.4 \mathrm{~Hz}, 1 \mathrm{H}), 6.86(\mathrm{~s}, 2 \mathrm{H}), 6.11$ $(\mathrm{d}, J=2.4 \mathrm{~Hz}, 1 \mathrm{H}), 5.96(\mathrm{~d}, J=2.4 \mathrm{~Hz}, 1 \mathrm{H}), 5.81(\mathrm{~s}, 1 \mathrm{H}), 3,95(\mathrm{~s}, 6 \mathrm{H}), 3,91(\mathrm{~s}, 3 \mathrm{H}), 3,84(\mathrm{~s}, 3 \mathrm{H}) .{ }^{13} \mathrm{C}$ RMN $\left(\mathrm{CDCl}_{3}, 68 \mathrm{MHz}\right): \delta 192.6,168.6,166.3,162.6,147.5,143.2,137.4,127.7,125.7,106.5,105.7,94.1,91.5$, $56.5,55.9,55.7$.

Demethylation procedure: Chalcone $\mathbf{1 3}$ or $\mathbf{1 5}$ in solution in $3 \mathrm{~mL}$ of dry DCM is treated with $3 \mathrm{eq}$ of $\mathrm{AlCl}_{3}$ for three days at room temperature. The reaction mixture is then hydrolyzed with $6 \mathrm{~mL}$ of $0.5 \mathrm{M}$ aqueous $\mathrm{HCl}$ solution and extracted with DCM $(3 \times 10 \mathrm{~mL})$. The combined organic extracts are dried over sodium sulfate and evaporated under reduced pressure. The phenolic chalcone is purified through flash chromatography.

(E)-3-(4-hydroxy-3,5-dimethoxyphenyl)-1-(2-hydroxy-4-methoxyphenyl)prop-2-en-1-one (12). The above procedure is applied to $200 \mathrm{mg}$ of chalcone 13. The conversion rate is estimated at $75 \%$ after column chromatography with cyclohexane-EtOAc (8:2) as the mobile phase, $56 \mathrm{mg}$ of $\mathbf{1 2}$ as a yellow powder are obtained (brsm yield: 39\%). ${ }^{1} \mathrm{H}$ NMR $\left(\mathrm{CDCl}_{3}, 270 \mathrm{MHz}\right): \delta 13.54(\mathrm{~s}, 1 \mathrm{H}), 7.84(\mathrm{dd}, J=7.8 \mathrm{~Hz}, 1.6$ $\mathrm{Hz}, 1 \mathrm{H}), 7.81(\mathrm{~d}, J=15.4 \mathrm{~Hz}, 1 \mathrm{H}), 7.42(\mathrm{~s}, J=15.3 \mathrm{~Hz}, 1 \mathrm{H}), 6.89(\mathrm{~s}, 2 \mathrm{H}), 6.49(\mathrm{dd}, J=8.9 \mathrm{~Hz}, 2.4 \mathrm{~Hz}, 1 \mathrm{H})$, $6.48(\mathrm{~d}, J=1.5 \mathrm{~Hz}, 1 \mathrm{H}), 5.87(\mathrm{~s}, 1 \mathrm{H}), 3.97(\mathrm{~s}, 6 \mathrm{H}), 3.87(\mathrm{~s}, 3 \mathrm{H}) .{ }^{13} \mathrm{C} \mathrm{RMN}\left(\mathrm{CDCl}_{3}, 68 \mathrm{MHz}\right): \delta 191.9,166.9$, 166.3, 147.5, 145.2, 137.9, 131.3, 126.5, 118.2, 114.3, 107.9, 105.9, 101.2, 56.6, 55.7.

(E)-1-(2-hydroxy-4-methoxyphenyl)-3-(3,4,5-trimethoxyphenyl)prop-2-en-1-one (14). The above procedure is applied to $45 \mathrm{mg}$ of chalcone 15. After preparative TLC with cyclohexane-EtOAc (7:3) as the mobile phase, $18 \mathrm{mg}$ of 12 as a yellow powder are obtained. Yield $41 \% .{ }^{1} \mathrm{H} \mathrm{NMR}\left(\mathrm{CDCl}_{3}, 270 \mathrm{MHz}\right): \delta 13.48(\mathrm{~s}$, 
1H), 7.91-7.72 (m, 1H), $7.82(\mathrm{~d}, J=15,3 \mathrm{~Hz}, 1 \mathrm{H}), 7.46(\mathrm{~d}, J=15.3 \mathrm{~Hz}, 1 \mathrm{H}), 6.88(\mathrm{~s}, 2 \mathrm{H}), 6.53-6.48(\mathrm{~m}, 1 \mathrm{H})$, 6.49-6.48 (m, 1H), $3.95(\mathrm{~s}, 6 \mathrm{H}), 3.92(\mathrm{~s}, 3 \mathrm{H}), 3.88(\mathrm{~s}, 3 \mathrm{H})$. HRMS FAB [M + H] 345.1347.

Ethyl (E)-2-(4-(3-(2,4-dimethoxyphenyl)-3-oxoprop-1-en-1-yl)-2,6-dimethoxyphenoxy)acetate (19). To a solution of chalcone $13(141 \mathrm{mg}, 0.42 \mathrm{mmol})$ in $7 \mathrm{~mL}$ of dry DMF are added $116 \mathrm{mg}$ of potassium carbonate $\left(\mathrm{K}_{2} \mathrm{CO}_{3}\right)(2 \mathrm{eq})$ and $0.7 \mathrm{~mL}$ of ethyle $\alpha$-bromoacetate $(1.5 \mathrm{eq})$. The reaction mixture is stirred at RT for $24 \mathrm{~h}$ and then filtered. After dilution with water, the product is extracted with DCM. The combined organic extracts are dried over anhydrous sodium sulfate. The solvent is removed under reduced pressure. The crude product is purified through silica gel column chromatography using cyclohexane-AcOEt (7:3) as a mobile phase to lead to $92 \mathrm{mg}$ of $\mathbf{1 9}$ (Yield: 51\%).

(E)-2-(4-(3-(2,4-dimethoxyphenyl)-3-oxoprop-1-en-1-yl)-2,6-dimethoxyphenoxy)acetic acid (20). Ester 19 $(83 \mathrm{mg}, 0.21 \mathrm{mmol})$ is dissolved in tetrahydrofuran (THF) $(3 \mathrm{~mL})$ and water $(0.6 \mathrm{~mL})$ with $26 \mathrm{mg}$ of lithium hydroxide monohydrate $\left(\mathrm{LiOH} . \mathrm{H}_{2} \mathrm{O}\right)(3 \mathrm{eq})$. The reaction mixture is stirred at room temperature overnight. After removal of the solvent, the resulting mixture is neutralized and extracted with ethyl acetate $(3 \times 15 \mathrm{~mL})$. The combined extracts are dried over sodium sulfate, evaporated. The final product is recrystallized in cold isopropyl ether to yield 20 as a yellow solid. (Yield $42 \%$ ) ${ }^{1} \mathrm{H}$ NMR $\left(\mathrm{CDCl}_{3}, 270 \mathrm{MHz}\right): \delta 7.75(\mathrm{~d}, J=8.6 \mathrm{~Hz}, 1 \mathrm{H}), 7.57(\mathrm{~d}, J=15.7 \mathrm{~Hz}, 1 \mathrm{H}), 7.40(\mathrm{~d}, J=15.7 \mathrm{~Hz}, 1 \mathrm{H}), 6.84(\mathrm{~s}$, 2H), $6.58(\mathrm{dd}, J=8.6,2.3 \mathrm{~Hz}, 1 \mathrm{H}), 6.51(\mathrm{~d}, J=2.2 \mathrm{~Hz}, 1 \mathrm{H}), 4.65(\mathrm{~d}, J=2.6 \mathrm{~Hz}, 2 \mathrm{H}), 3.95(\mathrm{~s}, 6 \mathrm{H}), 3.91(\mathrm{~s}$, $3 \mathrm{H}), 3.88$ (s, 3H). ${ }^{13} \mathrm{C}$ NMR $\left(\mathrm{CDCl}_{3}, 68 \mathrm{MHz}\right): \delta 190.5,170.5,164.6,160.7,152.3,141.4,137.9,133.1,132.9$, $127.9,122.2,105.5,105.3,98.9,56.4,55.9,55.7$.

\subsection{Calculated $\log P$}

Prediction of absorption was performed with the $\log P$ calculated with ACD/Labs software predictor (v11.02, Toronto, Canada).

\subsection{Animals}

The present protocol has been approved by the Pays de la Loire (France) ethics committee (20 April 2012) under the register code CEEA.2012.202 and is conformed to the Guide for the Care and Use of Laboratory Animals published by U.S. National Institutes of Health (NIH Publication No. 85-23, revised 1996). Both wild type (WT) and whole-bod knock out (KO) mice were kept at ambient temperature under 12/12-h light/dark circadian conditions and fed standard rodent chow ad libitum and used between 12 to 16 weeks old.

\subsection{Vascular Reactivity}

Female ER $\alpha$ WT or KO C57Bl/ 6 mice were ovariectomized at the age of $14 \pm 2$ weeks. After 7 days, the thoracic aortas were isolated and dissected in a physiological saline solution (PSS) ( $\mathrm{NaCl} 130 \mathrm{mM}$, $\mathrm{NaHCO}_{3} 14.9 \mathrm{mM}, \mathrm{KCl} 3.7 \mathrm{mM}, \mathrm{KH}_{2} \mathrm{PO}_{4} 1.2 \mathrm{mM}, \mathrm{MgSO}_{4} .7 \mathrm{H}_{2} \mathrm{O} 1.2 \mathrm{mM}, \mathrm{CaCl}_{2} \cdot \mathrm{H}_{2} \mathrm{O} 1.6 \mathrm{mM}$, glucose $11 \mathrm{mM}, \mathrm{pH}=7.40$ ) and mounted on a wire myograph filled with physiological saline solution (PSS), at $37{ }^{\circ} \mathrm{C}$, under a flow of a gas composed by $20 \% \mathrm{O}_{2}, 5 \% \mathrm{CO}_{2}$ and $75 \% \mathrm{~N}_{2}$. Mechanical activity was recorded isometrically by a force transducer (Danish Myo Technology, Aarhus, Denmark). Since it has been described that the chalcone isoliquiritigenin exerted a vasorelaxant effect for concentrations ranging from $10^{-7} \mathrm{M}$ to $10^{-4} \mathrm{M}\left(2 \times 10^{-5} \mathrm{~g} / \mathrm{L}\right.$ to $\left.2 \times 10^{-2} \mathrm{~g} / \mathrm{L}\right)$ [15] and that synthetic anthocynidins exerted a vasorelaxant effect for concentrations ranging from $10^{-5} \mathrm{~g} / \mathrm{L}$ to $10^{-2} \mathrm{~g} / \mathrm{L}[9]$, synthetic chalcones were tested for a similar concentrations range $\left(10^{-5} \mathrm{~g} / \mathrm{L}\right.$ to $\left.10^{-2} \mathrm{~g} / \mathrm{L}\right)$. Concentration-response curves were constructed by the cumulative addition of the initial solution of the molecules $(0.1,1,10 \mathrm{~g} / \mathrm{L})$ to reach the following final concentrations in $\mathrm{g} / \mathrm{L}: 10^{-5}, 10^{-4}, 3 \times 10^{-4}, 10^{-3}, 3 \times 10^{-3}, 10^{-2}$. Vessels were pre-contracted with U46619, phenylephrine, and serotonin, at $80 \%$ of their maximal response. The presence of functional endothelium was assessed by determining the ability of acetylcholine $(10 \mu \mathrm{M})$ to induce more than $50 \%$ relaxation of pre-contracted rings. The same protocol was carried out in presence of $100 \mu \mathrm{M}$ of L-NAME 20 minutes before the addition of the precontracting agents. 


\subsection{Statistical Analysis}

The statistical significance of the differences between samples was determined using the Mann-Whitney test. Differences were considered significant for $p<0.05$. All statistical tests were carried out with GraphPad Prism 5 (GraphPad Software, Inc, San Diego, CA, USA).

Author Contributions: Conceptualization, S.L., S.F. and J.-J.H.; investigation, S.L., K.T., Y.A. and J.-J.H.; writing-original draft preparation, S.L. and J.-J.H. All authors have read and agreed to the published version of the manuscript.

Funding: This research received no external funding.

Acknowledgments: This work has been achieved in part in the INSERM U1063, Stress Oxydant et Pathologies Métaboliques, IBS-IRIS, UNIV Angers. We want to sincerely thank Mireille Wertheimer for the careful breeding of mice, Dr Nicolas Clere, Dr Abderahim Gaceb and Gregory Hilairet for their precious advice and suggestions.

Conflicts of Interest: The authors declare no conflict of interest.

\section{Abbreviations}

\begin{tabular}{|c|c|}
\hline ACE & Angiotensin converting enzyme \\
\hline $\mathrm{AlCl}_{3}$ & Aluminum chloride \\
\hline $\mathrm{BK}_{\mathrm{Ca}}$ & Calcium-activated potassium channel-dependent \\
\hline brsm & Based on recovered starting material \\
\hline cLogP & Calculated octanol-water partition coefficient \\
\hline CVDs & Cardiovascular diseases \\
\hline DCM & Dichloromethane \\
\hline eNOS & Endothelial nitric oxide synthase \\
\hline $\mathrm{ER} \alpha$ & Estrogen receptor $\alpha$ \\
\hline $\mathrm{ER} \beta$ & Estrogen receptor $\beta$ \\
\hline EtOAc & Ethyl acetate \\
\hline $\mathrm{EtOH}$ & Ethanol \\
\hline $\mathrm{HCl}$ & Hydrochloric acid \\
\hline $\mathrm{K}_{2} \mathrm{CO}_{3}$ & Potassium carbonate \\
\hline $\mathrm{KO}$ & Knock out \\
\hline $\mathrm{KOH}$ & Potassium hydroxide \\
\hline L-NAME & $\mathrm{N} \omega$-nitro-L-arginine methyl ester \\
\hline LiOH. $\mathrm{H}_{2} \mathrm{O}$ & Lithium hydroxide monohydrate \\
\hline $\mathrm{MOM}$ & Methoxymethyl \\
\hline MW & Microwave \\
\hline $\mathrm{NO}$ & Nitric oxide \\
\hline $\mathrm{OCH}_{3}$ & Methoxyl \\
\hline $\mathrm{OH}$ & Hydroxyl \\
\hline PSS & Physiological saline solution \\
\hline PKG & Protein kinase $\mathrm{G}$ \\
\hline RT & Room temperature \\
\hline SAR & Structure-activity relationships \\
\hline sGC & Soluble guanylyl cyclase \\
\hline $\mathrm{SOCl}_{2}$ & Thionyl chloride \\
\hline THF & Tetrahydrofuran \\
\hline TLC & Thin-layer chromatography \\
\hline $\mathrm{WHO}$ & World health organization \\
\hline WT & Wilde type \\
\hline
\end{tabular}




\section{References}

1. WHO|About Cardiovascular Diseases. Available online: https://www.who.int/cardiovascular_diseases/ about_cvd/en/ (accessed on 26 November 2019).

2. Woollard, K.J. Immunological aspects of atherosclerosis. Clin. Sci. Lond. Engl. 1979 2013, 125, $221-235$. [CrossRef] [PubMed]

3. Konukoglu, D.; Uzun, H. Endothelial Dysfunction and Hypertension. Adv. Exp. Med. Biol. 2017, 956, 511-540.

4. Roger, V.L.; Go, A.S.; Lloyd-Jones, D.M.; Adams, R.J.; Berry, J.D.; Brown, T.M.; Carnethon, M.R.; Dai, S.; de Simone, G.; Ford, E.S.; et al. Heart disease and stroke statistics-2011 update: A report from the American Heart Association. Circulation 2011, 123, e18-e209. [CrossRef] [PubMed]

5. Stanhewicz, A.E.; Wenner, M.M.; Stachenfeld, N.S. Sex differences in endothelial function important to vascular health and overall cardiovascular disease risk across the lifespan. Am. J. Physiol. Heart Circ. Physiol. 2018, 315, H1569-H1588. [CrossRef] [PubMed]

6. Arnal, J.-F.; Lenfant, F.; Metivier, R.; Flouriot, G.; Henrion, D.; Adlanmerini, M.; Fontaine, C.; Gourdy, P.; Chambon, P.; Katzenellenbogen, B.; et al. Membrane and Nuclear Estrogen Receptor Alpha Actions: From Tissue Specificity to Medical Implications. Physiol. Rev. 2017, 97, 1045-1087. [CrossRef] [PubMed]

7. Arnal, J.-F.; Fontaine, C.; Billon-Galés, A.; Favre, J.; Laurell, H.; Lenfant, F.; Gourdy, P. Estrogen receptors and endothelium. Arterioscler. Thromb. Vasc. Biol. 2010, 30, 1506-1512. [CrossRef] [PubMed]

8. Chalopin, M.; Tesse, A.; Martínez, M.C.; Rognan, D.; Arnal, J.-F.; Andriantsitohaina, R. Estrogen receptor alpha as a key target of red wine polyphenols action on the endothelium. PLoS ONE 2010, 5, e8554. [CrossRef]

9. Legeay, S.; Trân, K.; Abatuci, Y.; Justiniano, H.; Lugnier, C.; Duval, O.; Helesbeux, J.-J.; Faure, S. Design, Synthesis, Pharmacological Evaluation and Vascular Effects of Delphinidin Analogues. Curr. Pharm. Des. 2018, 24, 5580-5589. [CrossRef]

10. Cobin, R.H.; Goodman, N.F. American association of clinical endocrinologists and american college of endocrinology position statement on menopause-2017 update. Endocr. Pract. 2017, 23, 869-880. [CrossRef]

11. Knowlton, A.A.; Lee, A.R. Estrogen and the cardiovascular system. Pharmacol. Ther. 2012, 135, 54-70. [CrossRef]

12. Kim, Y.; Je, Y. Flavonoid intake and mortality from cardiovascular disease and all causes: A meta-analysis of prospective cohort studies. Clin. Nutr. ESPEN 2017, 20, 68-77. [CrossRef] [PubMed]

13. Tressera-Rimbau, A.; Arranz, S.; Eder, M.; Vallverdú-Queralt, A. Dietary Polyphenols in the Prevention of Stroke. Oxid. Med. Cell. Longev. 2017, 2017, 7467962. [CrossRef]

14. Keli, S.O.; Hertog, M.G.; Feskens, E.J.; Kromhout, D. Dietary flavonoids, antioxidant vitamins, and incidence of stroke: The Zutphen study. Arch. Intern. Med. 1996, 156, 637-642. [CrossRef] [PubMed]

15. Ye, Y.; Gao, M.; Feng, L.; Feng, B.; Ma, X. Isoliquiritigenin-induced vasodilation by activating large-conductance $\mathrm{Ca}^{2+}$-activated $\mathrm{K}^{+}$channels in mouse mesenteric arteries. Clin. Exp. Pharmacol. Physiol. 2019, 46, 1044-1052. [CrossRef] [PubMed]

16. Avila-Villarreal, G.; Hernández-Abreu, O.; Hidalgo-Figueroa, S.; Navarrete-Vázquez, G.; Escalante-Erosa, F.; Peña-Rodríguez, L.M.; Villalobos-Molina, R.; Estrada-Soto, S. Antihypertensive and vasorelaxant effects of dihydrospinochalcone-A isolated from Lonchocarpus xuul Lundell by NO production: Computational and ex vivo approaches. Phytomedicine Int. J. Phytother. Phytopharm. 2013, 20, 1241-1246. [CrossRef]

17. Muchtaridi, M.; Syahidah, H.N.; Subarnas, A.; Yusuf, M.; Bryant, S.D.; Langer, T. Molecular Docking and 3D-Pharmacophore Modeling to Study the Interactions of Chalcone Derivatives with Estrogen Receptor Alpha. Pharm. Basel Switz. 2017, 10, 81. [CrossRef]

18. Andriambeloson, E.; Kleschyov, A.L.; Muller, B.; Beretz, A.; Stoclet, J.C.; Andriantsitohaina, R. Nitric oxide production and endothelium-dependent vasorelaxation induced by wine polyphenols in rat aorta. Br. J. Pharmacol. 1997, 120, 1053-1058. [CrossRef]

19. Andriambeloson, E.; Magnier, C.; Haan-Archipoff, G.; Lobstein, A.; Anton, R.; Beretz, A.; Stoclet, J.C.; Andriantsitohaina, R. Natural dietary polyphenolic compounds cause endothelium-dependent vasorelaxation in rat thoracic aorta. J. Nutr. 1998, 128, 2324-2333. [CrossRef]

20. Neves, M.P.; Cravo, S.; Lima, R.T.; Vasconcelos, M.H.; Nascimento, M.S.J.; Silva, A.M.S.; Pinto, M.; Cidade, H.; Corrêa, A.G. Solid-phase synthesis of 2'-hydroxychalcones. Effects on cell growth inhibition, cell cycle and apoptosis of human tumor cell lines. Bioorg. Med. Chem. 2012, 20, 25-33. [CrossRef] 
21. Vásquez-Martínez, Y.A.; Osorio, M.E.; San Martín, D.A.; Carvajal, M.A.; Vergara, A.P.; Sanchez, E.; Raimondi, M.; Zacchino, S.A.; Mascayano, C.; Torrent, C.; et al. Antimicrobial, Anti-Inflammatory and Antioxidant Activities of Polyoxygenated Chalcones. J. Braz. Chem. Soc. 2019, 30, 286-304. [CrossRef]

22. Petrov, O.; Ivanova, Y.; Gerova, M. SOCl2/EtOH: Catalytic system for synthesis of chalcones. Catal. Commun. 2008, 9, 315-316. [CrossRef]

23. Roussaki, M.; Hall, B.; Lima, S.C.; da Silva, A.C.; Wilkinson, S.; Detsi, A. Synthesis and anti-parasitic activity of a novel quinolinone-chalcone series. Bioorg. Med. Chem. Lett. 2013, 23, 6436-6441. [CrossRef] [PubMed]

24. Shirali, A.; Sriram, M.; Hall, J.J.; Nguyen, B.L.; Guddneppanavar, R.; Hadimani, M.B.; Ackley, J.F.; Siles, R.; Jelinek, C.J.; Arthasery, P.; et al. Development of synthetic methodology suitable for the radiosynthesis of combretastatin A-1 (CA1) and its corresponding prodrug CA1P. J. Nat. Prod. 2009, 72, 414-421. [CrossRef] [PubMed]

25. Mahapatra, D.K.; Bharti, S.K. Therapeutic potential of chalcones as cardiovascular agents. Life Sci. 2016, 148, 154-172. [CrossRef]

26. Sherman, G.P.; Packman, E.W.; Rossi, G.V. Electrolyte Alterations in Vascular Smooth Muscle and Hypotensive Activity of a New Chalcone derivative. J. Pharm. Sci. 1968, 57, 733-737. [CrossRef]

27. Wu, C.-M.; Lin, K.-W.; Teng, C.-H.; Huang, A.-M.; Chen, Y.-C.; Yen, M.-H.; Wu, W.-B.; Pu, Y.-S.; Lin, C.-N. Chalcone derivatives inhibit human platelet aggregation and inhibit growth in human bladder cancer cells. Biol. Pharm. Bull. 2014, 37, 1191-1198. [CrossRef]

28. Yarishkin, O.V.; Ryu, H.W.; Park, J.-Y.; Yang, M.S.; Hong, S.-G.; Park, K.H. Sulfonate chalcone as new class voltage-dependent K+ channel blocker. Bioorg. Med. Chem. Lett. 2008, 18, 137-140. [CrossRef]

29. Casaschi, A.; Maiyoh, G.K.; Rubio, B.K.; Li, R.W.; Adeli, K.; Theriault, A.G. The chalcone xanthohumol inhibits triglyceride and apolipoprotein B secretion in HepG2 cells. J. Nutr. 2004, 134, 1340-1346. [CrossRef]

30. Tabata, N.; Ito, M.; Tomoda, H.; Omura, S. Xanthohumols, diacylglycerol acyltransferase inhibitors, from Humulus lupulus. Phytochemistry 1997, 46, 683-687. [CrossRef]

31. Hirata, H.; Takazumi, K.; Segawa, S.; Okada, Y.; Kobayashi, N.; Shigyo, T.; Chiba, H. Xanthohumol, a prenylated chalcone from Humulus lupulus L., inhibits cholesteryl ester transfer protein. Food Chem. 2012, 134, 1432-1437. [CrossRef]

32. Zhang, X.-H.; Li, C.-Y.; Lin, Q.-H.; He, Z.-H.; Feng, F.; He, M.-F. Pro-angiogenic activity of isoliquiritin on HUVECs in vitro and zebrafish in vivo through Raf/MEK signaling pathway. Life Sci. 2019, 223, 128-136. [CrossRef] [PubMed]

33. Oh, Y.J.; Seo, Y.H. A novel chalcone-based molecule, BDP inhibits MDA-MB-231 triple-negative breast cancer cell growth by suppressing Hsp90 function. Oncol. Rep. 2017, 38, 2343-2350. [CrossRef] [PubMed]

34. Kim, K.H.; Young, B.D.; Bender, J.R. Endothelial estrogen receptor isoforms and cardiovascular disease. Mol. Cell. Endocrinol. 2014, 389, 65-70. [CrossRef] [PubMed]

35. Iorga, A.; Cunningham, C.M.; Moazeni, S.; Ruffenach, G.; Umar, S.; Eghbali, M. The protective role of estrogen and estrogen receptors in cardiovascular disease and the controversial use of estrogen therapy. Biol. Sex Differ. 2017, 8, 33. [CrossRef]

36. Chakrabarti, S.; Morton, J.S.; Davidge, S.T. Mechanisms of estrogen effects on the endothelium: An overview. Can. J. Cardiol. 2014, 30, 705-712. [CrossRef]

37. Dong, X.; Chen, J.; Jiang, C.; Liu, T.; Hu, Y. Design, synthesis, and biological evaluation of prenylated chalcones as vasorelaxant agents. Arch. Pharm. (Weinh.) 2009, 342, 428-432. [CrossRef]

38. Chen, Z.; Hu, Y.; Wu, H.; Jiang, H. Synthesis and vasorelaxation action of flavonoids. Yao Xue Xue Bao 2005, $40,1001-1007$.

(C) 2020 by the authors. Licensee MDPI, Basel, Switzerland. This article is an open access article distributed under the terms and conditions of the Creative Commons Attribution (CC BY) license (http://creativecommons.org/licenses/by/4.0/). 